\title{
Global intellectual search and hemispheric balancing acts: the international face of Brazil's quest for national development in the Cold War
}

\author{
Rafael R. Ioris ${ }^{1}$
}

\begin{abstract}
Even though during its so-called developmentalist period Brazilian leaders sought to actively engage with similar events taking place globally, the historiography on the period continues to be remarkably silent on these important intellectual and political connections. The present article seeks to address this analytical silence by offering a comparative assessment of development-related reflections taking place in Brazil as well as in other parts of the emergent world in the aftermath of World War II. The piece also examines how the Brazilian government promoted its developmental goals by engaging in innovative foreign policy projects (e.g. Operation Pan-America) as a way to demonstrate the convergence between domestic developmental ideas and the country's main international diplomatic actions.
\end{abstract}

Key words: Brazil, developmentalism, foreign policy, intellectuals, Third World, Operation Pan-America.

\section{Busca intelectual global e Atos de equilíbrio hemisférico: A face internacional da promoção de desenvolvimento nacional do Brasil na Guerra Fria}

Resumo Embora durante a fase áurea do desenvolvimentismo, líderes brasileiros buscassem se engajar com eventos e ideias ligadas à temática do desenvolvimento nacional ocorrendo ao redor do mundo, a historiografia do período continua, em linhas gerais, ainda marcada por um viés eminentemente nacionalista. $\mathrm{O}$ presente artigo busca rever essa situação por meio de uma avaliação comparativa da reflexão desenvolvimentista ocorrendo no Brasil em outras partes do chamado mundo emergente. O texto examina também como o governo brasileiro buscou promover o desenvolvimento do pais por meio de projetos inovadores de política externa como

\footnotetext{
1 Doutor em História Latino-Americana pela Universidade Emory. Professor Associado de História Latino-Americana da Universidade de Denver. Pesquisa em andamento: Projetos de cooperação frustrada nas Relações Brasil-Estados Unidos no contexto da Aliança para o Progresso. Endereço profissional: University of Denver. 2000 E. Asbury Ave., Sturm Hall \#367 Denver, CO 80208 Ph: 303-871-2950. http://www.du.edu/ahss/ history/facultystaff/ioris. html. E-mail: rafael.ioris@du.edu
}

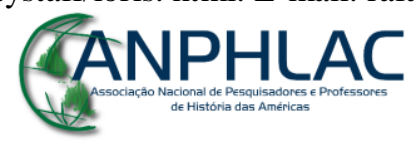

Revista Eletrônica da ANPHLAC, ISSN 1679-1061, №. 22, p. 296-326, Jan./Jun., 2017.

http://revista.anphlac.org.br 
forma de demonstrar a convergência entre o ideário doméstico e ações políticas no meio internacional.

Palavras-Chave: Brasil, Desenvolvimentismo, Política Externa, Intelectuais, Terceiro Mundo, Operação Pan-Americana.

Artigo recebido em: 01/09/2016

Artigo aprovado para publicação em: 16/02/2017

\section{Introduction}

In the aftermath of World War II, Brazil witnessed high rates of economic growth, the deepening of its process of industrialization, and many sectors of its national elites believed their country was about to embark upon a new historical path which should be translated into a more autonomous path of national development and more assertive forms of participation in the international arena. Considering the high degree to which these transformative events impacted the domestic context, particularly in the 1950s, several studies assessing the period have focused on its economic achievements and the associated broad sense of optimism among some of the country's most influential political actors. Though plentiful and still useful as a general political portrayal of the time, this important scholarly production is nonetheless almost entirely silent on how internal events interfaced with similar trends taking place concomitantly in other parts of the world. ${ }^{2}$

This is especially surprising considering that, as early as in the late 1940s, prolific discussions on the topics of national development and industrialization were noticeable in several countries undergoing the process of political decolonization. To be sure, in 1947, in New Delhi, and then again in 1954, in Colombo, representatives from

\footnotetext{
2 Among the many works advancing this line of argument, the most influential are BENEVIDES, 1976; FASSY, 2000; GOMES, 1991; LOUZEIRO, 1996; FERREIRA DOS SANTOS, 1997; GOMES SANTOS, 2002; RODRIGUES, 1994; SILVA; CARNEIRO, 1983.

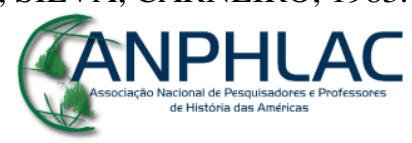

Revista Eletrônica da ANPHLAC, ISSN 1679-1061, №. 22, p. 296-326, Jan./Jun., 2017.

http://revista.anphlac.org.br
} 
several recently emancipated nations gathered to discuss the challenges and prospects they shared newly independent societies. These initiatives proved especially relevant in a rigidly divided and polarized world and this budding cooperative endeavor only intensified in 1955 when representatives from 28 newly independent nations met in Bandung to advance an autonomous agenda of national development. Thus, considered from a broader perspective the dynamic historical experiences involved in the emergence of the ever more complex world order that started unfolding at the time, it is clear that the events taking place in Brazil in the 1950s should no longer be examined exclusively from a purely domestic perspective.

Aimed at moving beyond the traditional nation-centered approach, this article seeks to demonstrate how the prolific debates and policies formulated in Brazil in those years were closely paralleled with similar events taking place in the regional, hemispheric, as well as global realms. One of the main arguments advanced here is that during the so-called developmentalist decade a new kind of indirect yet mutually reinforcing interaction between the political projects and ideational propositions unfolding in the domestic arenas and associated dynamics occurring globally started taking shape. Likewise, in examining the relevant case of Brazil, by examining key elements of the Operation Pan-America - the new and most ambitious foreign policy project advanced by Juscelino Kubitschek, Brazil's president between 1956 and 1961 I indicate the convergence between influential notions articulated by key national decision-makers and those involved in chief diplomatic initiatives of the time.

In undertaking these two analytical goals, the article argues that by pursuing fast-paced national development on the basis of state planning and intervention in the national economy, as well as strengthened ties with key operators of global capitalism, Brazilian elites trailed a challenging balance between aspired autonomy and higher interdependence. Along this path, decision-makers pledged to remain within the Capitalist order, while also expecting higher rewards for doing so. Similarly, they sought to promote a course of economic empowerment within the private enterprise system while, at the same time, challenging the limits of the international, and

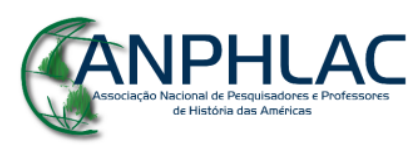

Revista Eletrônica da ANPHLAC, ISSN 1679-1061, №. 22, p. 296-326, Jan./Jun., 2017.

http://revista.anphlac.org.br 
hemispheric market-oriented economic ideas sustaining the nation-centered model of development of the time. In following these innovative historical lines, Brazilian political leaders rightly saw the US government as the only public actor capable of supporting their developmental plans but also as the one who could forcefully curtail such efforts at will. This is why, in the end, despite their ambitious plans and assertive behavior, the course of the foreign policy pursued by Brazilian leaders in the transformative decade of the 1950s was as bold and imaginative as it was cautious and mostly insufficient to respond to the country's growing needs.

\section{Late-Development in a Global Perspective: the Pursuit for Alternatives}

The promotion of projects of fast-paced national development was the focus of governmental planning in a multitude of late-developing countries from the late $1800 \mathrm{~s}$ to the period of decolonization following the conclusion of the Second World War. Given the multiplicity of historical variations within which this phenomenon has taken place, different authors have categorized the main dynamics involved in governmentoriented development projects under different heuristic labels. One of the most influential studies on the experiences of countries pursuing fast-paced industrial promotion in the late 1800s was written in the 1960s by Alexander Gerschenkron, who studied the challenges developing economies faced in attempting to catch up with the already industrialized nations of Western Europe. In this view, the goal of industrializing via governmental planning was prominent in countries whose political leadership saw the economic condition of lagging behind as a matter of national survival and thus, as a condition to be overcome, if needed, by converting the central government into the most important agent of development promotion. (GERSCHENKRON, 1962) The entrepreneurial role of the state as the risk-taker of last resort for economic activities not commonly funded by private capital was also a crucial feature in the work of influential development scholar Albert O. Hirschman, whose examinations of postwar Latin America described the initially disruptive but ultimately

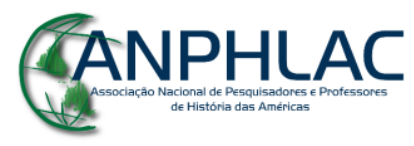

Revista Eletrônica da ANPHLAC, ISSN 1679-1061, №. 22, p. 296-326, Jan./Jun., 2017.

http://revista.anphlac.org.br 
positive role fast-paced economic growth by means of targeted public investments. (HIRSCHMAN, 1958; 1963)

These ideas were corroborated by the detailed historical examination of the Japanese developmental state proposed by Chalmers Johnson in the early 1980s, who advanced the view that the rapid gains achieved by Japan in the aftermath of WWII derived from the ability of the Japanese government to act as an overarching surrogate agency inducing transformative investment decisions by resorting to protective tariffs on imports, subsidized financial resources granted to selected industrial sectors, and state-financed infrastructure improvements. (JOHNSON, 1982) This analytical model was later applied to the experiences of other Asian economies such as those of South Korea and Taiwan, where central governmental planning "generat[ed] national economic plans, coordinate[ed] the efforts of individual business groups, target[ed] specific industrial projects, and resist[ed] political pressures from popular forces such as consumers and organized labor." (PEMPEL in WOO-CUMINGS, 1999, p. 139) 3 Analogous to the fragmented state capabilities said to exist in the Latin American developmental experiences with fast-paced, state-induced industrialization, these nations are said to have faced similar initial hurdles in putting together an efficient socalled developmental state but, in the end, are defined as having demonstrated a higher ability to remove traditional oligarchic interests and bureaucratic traditions from the decision-making process (EVANS, 1989, p. 561-587) ${ }^{4}$, as well as to exclude, in a much higher degree, growing and ever more mobilized popular sectors from participating in the political process. (SCHNEIDER in WOO-CUMINGS, 1999, p. 299) ${ }^{5}$ The

\footnotetext{
${ }^{3}$ See also Alice Amsden, Asia's Next Giant: South Korea and Late Industrialization. (New York: Oxford University Press, 1989) and Robert Wade, Governing the Market: Economic Theory and Role of Government in East Asian Industrialization. (Princeton: Princeton University Press, 1990).

${ }^{4}$ Similar notions are advanced in Frances Hagopian, The Politics of Oligarchy: The Persistence of Traditional Elites in Contemporary Brazil. (Ph.D. Dissertation, Department of Political Science, MIT, 1986) and Fernando Henrique Cardoso, Autoritarismo e Democratização. (Rio de Janeiro: Paz e Terra, 1975). A less negative portrayal of the Brazilian experiences, which are therein portrayed as an intermediary case of developmental efficiency is found in Helen Shapiro, State Intervention and industrialization: The Origins of the Brazilian Automotive Industry. (Ph.D. Dissertation, Department of Economics, Yale University, 1988) and Peter Evans, Embedded Autonomy: States \& Industrial Transformation. (Princeton: Princeton University Press, 1995).

${ }_{5}^{5}$ Another important comparison between the experiences of Latin American nations, particularly Brazil
}

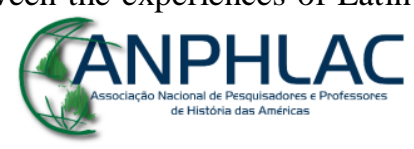

Revista Eletrônica da ANPHLAC, ISSN 1679-1061, №. 22, p. 296-326, Jan./Jun., 2017.

http://revista.anphlac.org.br 
characterization of the Brazilian (usually side-by-side the Indian and/or Mexican) experiences of fast-paced industrialization, in the 1950s and 60s, as an intermediate case within a range of successful and failed development promotion is by now, for better or worse, an established truism in the literature of developmental studies, and even more recent comparative works have reinforced such a view. ${ }^{6}$ But beyond the elements directly pertaining to the structures of the domestic state, wider structural economic and political factors should be taken into consideration when assessing the bold development projects taking place in agrarian economies in the second half of the century. In the 1950s, for one, even after many trade barriers had been formally removed by the 1947 United Nation's sponsored General Agreement on Tariffs and Trade (GATT), most of the agreement's provisions were not applicable to the exports of developing nations, as agricultural products remained subject to differential and higher tariffs $v i s-\grave{a}$-vis those applied to exports manufactured in already industrialized nations. In the Brazilian case, 62 percent of all of the country's export revenues in the $1950 \mathrm{~s}$ derived from the sales of coffee; a reality behind much of the nation's economic challenges in the period given that over the decade, especially after the end of the Korean War, global commodities prices, particularly that of coffee, faced a consistent decline. $^{7}$ This taxing, state of affairs was denounced by several critics over the years, particularly by those involved in campaigning for a new international economic order coalesced within the Non-Aligned Movement (NAM), early in the 1960s. (AHN, 1992) Similarly, even if originally involving exclusively Asian and African nations, the Bandung Conference of 1955 truly marked the beginning of a prolific dialogue, as well as promising partnership, between non-industrialized nations across the globe on the topic of national development. (QUEUILLE, 1965)

and Mexico, with those pertaining to the Korea and Taiwan, but one more focused on the international economic context can be found in Stephan Haggard, Pathways from the Periphery: The Politics of Growth in the Newly Industrializing Countries. (Ithaca, NY: Cornell University Press, 1990).

${ }^{6}$ See Vivek Chibber, Locked in Place: State-Building and Late Industrialization in India. (Princeton: Princeton University Press, 2003) and Atul Kohli, State-Directed Development: Political Power and Industrialization in the Global Periphery. (Cambridge: Cambridge University Press, 2004).

${ }^{7}$ Specific figures can be found in Presidência da República, Relatório geral de exportações e importações, 1947-1960. Rio de Janeiro, 1960.

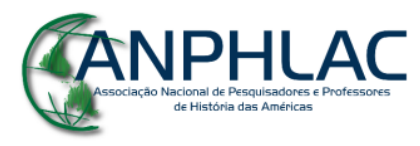

Revista Eletrônica da ANPHLAC, ISSN 1679-1061, №. 22, p. 296-326, Jan./Jun., 2017. 
But already in the latter part of the 1950s, the developmental demands and ideas been increasingly voiced in different parts of the globe would find resonance in analogous propositions advanced by Brazilian political leaders and nationalist intellectuals, particularly those coalesced at the, government-funded, think-tank-like Higher Institute of Brazilian Studies (Instituto Superior de Estudos Brasileiros, ISEB). ${ }^{8}$ Though no formal interaction ever existed between the leaders of the multilateral political engagements carried out in Asia and Africa (e.g. Nehru, Sukarno, Tito, etc.) and ISEB members, the arguments presented by Brazilian proponents of fast-paced industrialization were very much aligned with the discussions and projects undertaken by leaders of several recently independent Asian and African states. Kwame Nkrumah, the independence negotiator and first president of Ghana, for one, declared in 1958 that "[i]ndependence in itself does not change the world. It only makes possible the existence of the political environment required for the real process of national regeneration. If independence is the first step, development must come soon after and no leader of any African or Asian country can escape this pressure." (NKRUMAH, 1958, p. 1)

Following similar conceptual lines of their global counterparts, Brazilian leaders argued that only by pursuing an ambitious project of industrialization would their nations become effectively independent (i.e. economically self-sufficient). Also in tandem with influential formulations produced in the emerging newly independent world these writers posited that the main challenge underdeveloped countries faced rested on the fact their national economies were structurally defined by the co-existence of pre-capitalist economic activities with few dynamic export-oriented sectors. In the same way, ISEB authors sustained that underdeveloped economies were overly dependent on international commodity prices and demands prone to sharp fluctuations and contractions. Equally in tandem with the emerging critique coming out of the

\footnotetext{
${ }^{8}$ For a classic analysis of ISEB, see Caio Navarro de Toledo, ISEB: Fábrica de ideologias. (São Paulo: Ática, 1977). Recent works on the topic include by the same author, Intelectuais e política no Brasil: a experiência do ISEB. (São Paulo: Revan, 2005) and Rafael R. Ioris, Transforming Brazil: A History of National Development in the Postwar Era. (New York: Routledge, 2014).
}

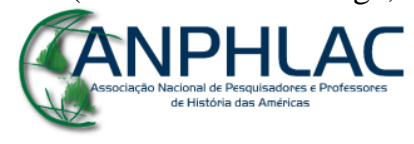

Revista Eletrônica da ANPHLAC, ISSN 1679-1061, №. 22, p. 296-326, Jan./Jun., 2017. 
recently emancipated states, already industrialized economies were likewise seen as responsible for the lack of economic alternatives available to underdeveloped (or developing) nations given their legacy of political or economic colonialism, which historically halted the emergence of a sense of national unity in the latter. ${ }^{9}$ What is more, drawing much of his ideas from comparing the case of Brazil with those of other non-industrialized societies, more specifically with the situation of the European colonies of the African continent which he saw as similarly culturally dependent societies, ISEB's Executive Director, Roland Corbisier, for one, argued, for one, that a self-sustaining path of development was what effectively defined the achievement of national (economic and cultural) autonomy or self-reliance, rather than its mere formal (legal) aspects. (CORBISIER, 1959, p. 22)

The unfolding historical parallels between Brazil's and more global emerging intellectual developmental trends notwithstanding, it is important to point out that although essentially critical of the main elements structuring their economies, Latin American and especially Brazilian mid-century developmental views were mostly organized mostly around a clear commitment to the goal of modernizing local capitalist modes of production along the lines of a nationalist rhetoric which assumed the national state to be a coherent entity promoting allegedly unified consensual goals, despite the deep historical race and class-based inequalities shaping their societies. ${ }^{11}$ In this sense, while Asian and African emergent nations increasingly, especially in the late 1960s and

\footnotetext{
${ }^{9}$ Some of the key works produced at the ISEB are Cândido Mendes de Almeida, Nacionalismo $e$ Desenvolvimento. (Rio de Janeiro: Instituto Brasileiro de Estudos Afro-Asiáticos, 1963); Hélio Jaguaribe, Condições Institucionais do Desenvolvimento. (Rio de Janeiro: ISEB, 1958); and Alvaro Vieira Pinto, Ideologia e Desenvolvimento Nacional. (Rio de Janeiro: ISEB, 1960).

${ }^{10}$ See also Corbisier, JK e a luta pela Presidência. (Rio de Janeiro: Duas Cidades, 1976), p. 155-157.

${ }^{11}$ For a critical analysis of these ideas, see H. W. Arndt, Economic Development: The History of an Idea. (Chicago: University of Chicago Press, 1987); Suzanne Bergeron, Fragments of Development: Nation, Gender, and the Space of Modernity. (Ann Arbor: University of Michigan Press, 2004); Peter J. Boetke, ed., The Collapse of Development Planning. (New York: New York University Press, 1994); Partha Chatterjee, Nationalist Thought and the Colonial World: A Derivative Discourse. (Minneapolis: University of Minnesota, 1993); Ian Roxborough, Theories of Underdevelopment. (London: Macmillan, 1979); and Immanuel Wallerstein, The Concept of National Development, 1917-1989: Elegy and Requiem. American Behavioral Scientist, 35: 517-529. For the latter, see James Scott, Seeing Like a State: How Certain Schemes to Improve the Human Condition Have Failed. (New Haven: Yale University Press, 1998); and Albert Fishlow, Some Reflections on Comparative Latin American Performance and Policy. (Helsinki: World Institute for Development Economics Research, 1987).
}

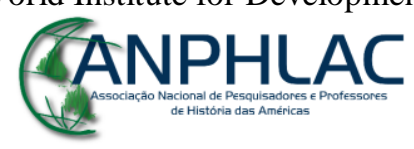

Revista Eletrônica da ANPHLAC, ISSN 1679-1061, №. 22, p. 296-326, Jan./Jun., 2017.

http://revista.anphlac.org.br 
70 s sought to overhaul the entire global economy towards the creation of a so-called New International Economic Order (NIEO), which, they hoped, would be able to move beyond the bipolar belligerent logic of the period; developing nations of the Western hemisphere continued to find themselves constricted within the limits of maneuverability allowed to them by their historically hegemonic and ever more powerful northern neighbor, the United States.

In fact, even prior to the Cuban experiences with the US-sponsored economic blockade and invasions of the early 60s, ISEB members, such as the agency's founder Hélio Jaguaribe, were very aware of the risks involved in pursuing a path of foreign policy that challenged the traditional influential role the United States played in the region. In spite of this recognition, the influential author nonetheless encouraged, to little avail at the time, Brazilian authorities to strengthen political ties with countries with similar developmental trajectories in the Latin American region so that their country could improve its historical bargaining position vis-à-vis the United States. (JAGUARIBE, 1958, p. 244-251) Moreover, and also indicating the limits of how far could a more independent course of foreign policy could have been undertaken by Brazilian authorities, leading sectors of the Brazilian military however believed that, by espousing such a notion of political autonomy, ISEB was going astray from its prescribed duties as an official, state-financed academic activities, thus becoming a subversive entity which paradoxically continued to receive institutional approval and logistical and financial support from an administration that prided itself for its "Christian ideals" and the defense of the Inter-American family of nations. ${ }^{12}$

Though relevant, these historical confines should not prevent us, however, from seeing the originality of the frame of analysis pursued in several parts of Latin America in the transformative years of the 1950s. In effect, towards moving beyond thus far available studies, the next section provides a general account of how important regional and especially Brazilian policy-makers attempted to convert their critical diagnosis and ideational formulations into concrete projects aimed at overcoming the state of

${ }^{12}$ Documento Secreto no. 003-B in Fundo Nelson Melo: NeM.vp. 1956.02.07, CPDOC Archive, Getúlio Vargas Foundation.

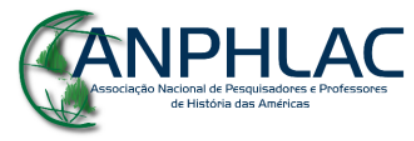

Revista Eletrônica da ANPHLAC, ISSN 1679-1061, №. 22, p. 296-326, Jan./Jun., 2017.

http://revista.anphlac.org.br 
underdevelopment in the Latin American context.

\section{Development in a Hemispheric Perspective and Brazil's Search for a New Historical Path}

As previously indicated, even though similarities existed between the goals and projects pursued by proponents of national development in Asian and Africa (as well as in portions of Southern Europe) and those pursued in Latin America in the aftermath of World War II, marked differences are also evident. ${ }^{13}$ For one, the search for an autonomous route of national development carried out by countries like India, Indonesia, and Egypt eventually coalesced into a unified effort, coordinated by the NonAligned Movement, which advanced an adamant anti Cold War rhetoric that demanded demilitarization, economic assistance, and the transfer of technology. (WALKER, 1993) Conversely, Latin American countries, and especially Brazil, traditionally accepted the dominant role of the United States in the Western hemisphere and, accordingly, their developmental quests assumed, in most cases, a more moderate course. (SACHS, 1969) In fact, even the Operation Pan-America (OPA), the innovative and ambitious new foreign policy directive that Kubitschek sought to implement, did not, in its underpinnings and implementation, represent a radical departure from the alignment Brazil maintained with the United States, but rather reflected a new attempt to direct the attention of the latter to Latin America's developmental needs, as will be demonstrated below.

Yet, even though the OPA did not amount to a radical departure from Brazil's key diplomatic principles (e.g. non-intervention, peaceful resolution of conflicts, pragmatism, etc.) - and the very fact that the Brazilian Foreign Service establishment did not enthusiastically support the ideas proposed by the president himself - , a

\footnotetext{
${ }^{13}$ Howard J. Wiarda called attention to the similarities between the experiences of national development promotion in the so-called Third World and Mediterranean countries such as Spain, Portugal, Greece, and even Italy. His argument is that both in Latin America and the Southern European countries a hierarchical, corporatist, patrimonial, and mercantilist traditional was in operation in the 1950s, when projects of fast economic growth were attempted. See also Claudio Veliz, The Centralist Tradition in Latin America. (Boulder: Westview Press, 1981).
}

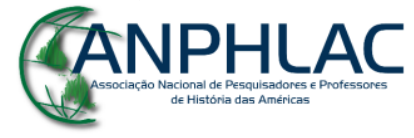

Revista Eletrônica da ANPHLAC, ISSN 1679-1061, №. 22, p. 296-326, Jan./Jun., 2017.

http://revista.anphlac.org.br 
reexamination of the traditional interpretations concerning Brazil's diplomatic history is still lacking. This is particularly true considering that the canonic historiography on the period argues that it took the coming of new idiosyncratic presidential administration to power, in 1961 for the country's foreign policy to assume an overtly developmental tone. ${ }^{14}$ To be sure, the new developmental tone assumed by Brazil's foreign policy initiatives already in the latter half of the 1950s reflected a historical trend taking place broadly in Latin America, a move which received its initial conceptual articulation in the aftermath of World War II, when local intellectuals began devising innovative ways to promote fast-paced economic growth in the region. At their core, these new political formulations posited that the very structure of international trade operated in ways constantly detrimental to produce-exporting economies, such those in Latin America. This principal proposition was best formulated and advanced in the Latin American context by scholars coalesced at the United Nations-sponsored Economic Commission for Latin America (ECLA) late in the 1940s and early 50s, whose main developmental argument posited that the global economy favored an unequal distribution of productivity gains between industrialized and non-industrialized countries. Conversely, the agency argued that regional governments, of mostly economies defined largely by agrarian-export commodity revenues devised specific policies favoring industrial projects via deliberate state intervention in order to rectify their challenging historical handicap. $^{15}$

Rapidly many of these innovative developmental propositions acquired a prominent place among other members of the Brazilian federal administration, among

\footnotetext{
${ }^{14}$ See Clodoaldo Bueno e Amado Cervo, A Política Externa Brasileira, 1822-1985. (São Paulo: Ática, 1986); Ricardo W. Caldas, A Política Externa do Governo Kubitscheck (Brasília: Thesaurus, 1996); Letícia Pinheiro, Ação e omissão: a ambiguidade da politica brasileira frente ao processo de descolonização africana, 1946-1960. (Dissertação de Mestrado defendida no Instituto de Relações Internacionais da PUC-RJ em 1988); Alexandra Mello e Silva, A Política Externa de JK: a Operação PanAmericana. (Dissertação de Mestrado defendida no Instituto de Relações Internacionais da PUC-RJ em 1992); Paulo G. F. Vizentini, As Relações Exteriores do Brasil:1945-1964. (Petrópolis: Vozes, 2004).

${ }^{15}$ See Raul Prebisch, The Economic Development of Latin America and its Principal Problems. (New York: United Nations Department of Economic Affairs, 1950). For synthetic view, view also Albert O. Hirschman, Ideologies of Economic Development in Latin America. In: Hirschman, ed., Latin American Issues, Essays, and Commnents. (New York: The Twentieth Century Fund, 1961); and Octavio Rodriguez, Teoria do Subdesenvolvimento da Cepal. (Rio de Janeiro: Forense Universitaria, 1981).
}

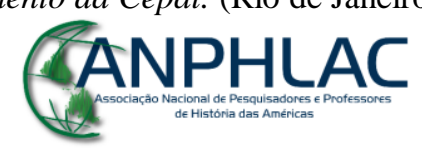

Revista Eletrônica da ANPHLAC, ISSN 1679-1061, №. 22, p. 296-326, Jan./Jun., 2017.

http://revista.anphlac.org.br 
them key figures participating in international conferences during those years. ${ }^{16}$ In a speech made at the meeting of the Social and Economic Council of the United Nations, in Geneva in August 1960, Vice-President João Goulart, for one, proclaimed Brazil's unequivocal commitment to the cause of fast-paced industrial promotion but demanded that:

[i]n an increasingly interdependent world, the fight against underdevelopment has to be fought not only domestically but requires new levels of international cooperation so that the trend towards growing disparities between rich and poor nations can be broken. (...) [e]very nation has the fundamental right of development even if this right is halted by the lack of multilateral coordination among the countries. Promoting development has, therefore, to be seen essentially as a collective responsibility of the international community. ${ }^{17}$

An analogous defense of the existence of a global responsibility held by industrialized countries in promoting industrial projects in the developing world was advanced by Gustavo Capanema, a senior member of the Brazilian National Chamber of Representatives, in 1956. A former Minister of Education and Health during the authoritarian regime of Estado Novo (1937-45), who served as head delegate of the Brazilian diplomatic commission to the United Nations-sponsored Conference on Development, Capanema claimed that "despite the liberal promises of development promotion made at the end of the [Second World] War, world trade dynamics continue to be characterized by an increasing deterioration of the terms of exchange of underdeveloped countries in direct contrast to the undergoing fast growth of the industrialized nations.", 18

At another multilateral conference of the postwar era, in New Delhi, in the same

\footnotetext{
${ }^{16}$ Classic analysis on how these ideas were disseminated rapidly in Brazil, especially among leading industrialists in both the National Confederation of Industry (CNI) and the powerful São Paulo Industrial Federation include Joseph L. Love, A construção do Terceiro Mundo: teorias do subdesenvolvimento na Romênia e no Brasil. (São Paulo: Paz e Terra, 1998); and Joseph L. Love, Raul Prebisch and the Origins of the Doctrine of Unequal Exchange. Latin American Research Review 15, no. 3 (1980): 45-72.

17 Fundo João Goulart: JG.vpr.1960.08.05, rolo 2, fot. 1221, CPDOC Archive, Getúlio Vargas Foundation, Rio de Janeiro.

${ }^{18}$ Gustavo Capanema, Discurso proferido pela delegação brasileira na segunda reunião preparatória para Conferência das Nações Unidas sobre Comércio e Desenvolvimento, em 21 de maio de 1956. Fundo Gustavo Capanema: GC L 1956.11.14, CPDOC Archive.
}

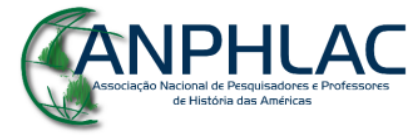

Revista Eletrônica da ANPHLAC, ISSN 1679-1061, №. 22, p. 296-326, Jan./Jun., 2017.

http://revista.anphlac.org.br 
year, Capanema further detailed the notion that Brazil had to strengthen ties with other developing countries as a way to promote the agenda of development on a world scale, going as far as declaring that "as Prime Minister Nehru has already stated, the true division in the world today is not the one between East and West, but rather that between the developed and the underdeveloped nations". ${ }^{19}$ Moreover, despite his traditional political moderation, this seasoned politician challenged all participating delegations in stating that "[i]f the prosperous nations of the world were effectively interested in promoting world peace, they should not raise objections to the creation of a global fund for promoting educational programs in favor of national development in poor countries." 20

Following very similar conceptual lines, another conservative politician--former governor of Minas Gerais and then Federal Senator--Benedito Valadares, also serving as head delegate of a Brazilian diplomatic mission--this time to the Eleventh Session of the United Nation General Assembly in 1956--criticized the difficulties that developing countries faced in obtaining the financial means necessary to promote their industrial goals. In his prepared speech, Valadares argued that existing inter-governmental (public) multilateral financial institutions (such as the World Bank) had yet to prove their genuine interest in supporting the legitimate goal of industrialization held by the nations of the emergent world. In effect, expressing one of the more radical utterances of a Brazilian diplomatic representative on the topic, the conservative Senator defended that "the transition from a stagnant economy to that of sustained growth in our economies, a necessary condition to meet the growing demands of our populations, is currently halted by those who have already reached the industrial stage. This is why," further argued the Brazilian delegate, "we strongly believe that industrialization is the only efficient solution to the old problem caused by the constant instability of prices and demands for primary exporting countries. ${ }^{21}$ Pursuing further his bold defense for global

${ }^{19}$ Gustavo Capanema, Opening Statement of the Head of the Brazilian Delegation at the New Delhi Conference on Education for Development of UNESCO, in November 1956. Fundo Gustavo Capanema: GC L 1956.05.23, p. 2, CPDOC Archive.

${ }^{20}$ Capanema, Opening Statement of the Head of the Brazilian, p. 9.

${ }^{21}$ Discours prononcé par le Sénateur Benedito Valadares, représentant du Brésil au Comité Economique

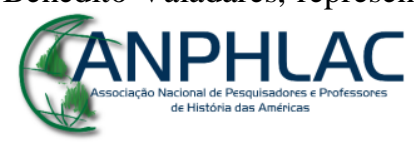

Revista Eletrônica da ANPHLAC, ISSN 1679-1061, №. 22, p. 296-326, Jan./Jun., 2017. 
developmental assistance from industrialized nations, Valadares went on to state that:

[o]nly by undergoing the process of becoming an industrialized society can we expect to provide an efficient answer to the persisting and anguishing condition faced by our agriculture-based economies, which are always at the risk of sudden disruptions originating from price and demand variations on the part of the industrial powers. (...) It is based on such an understanding that we poignantly defend the right of becoming industrialized and the notion that the already developed countries are those primarily responsible for making this possible. ${ }^{22}$

As demonstrated elsewhere, Brazilian proponents of accelerated development on the basis of state support included not nationalist intellectual, ruling political elites, domestic industrialists and most sectors of the armed forces, but also the majority of domestic urban middle classes and organized labor, as it has been well demonstrated elsewhere. (IORIS, 2014) ${ }^{23}$ Since these ambitious developmental concepts were behind the new developmental diplomatic projects unfolding in the latter part of the of the decade, in the next section I examine the main ideas underlining the most relevant foreign policy project carried out in Brazil in the 1950s, the Operation Pan-America. Of especial importance, I show that the Operation was clearly shaped by the overarching developmental goals of the administration and that these were not limited to the constraints of the domestic political sphere, but were rather translated into a new, multilateral, and economic-oriented direction for Brazilian diplomacy, at least in the Western hemisphere.

et Social de la 11 ieme Session de Assemblé Générale de l'ONU, sur le Problème de l'Assistance Technique aux Pais Sous-Développés. Speech made in New York, in November, 1956. Fundo Benedito Valadares BVa cs 1956.10.17, p. 8, photogram 856, CPDOC Archive.

${ }^{22}$ Valadares, Discours prononcé par le Sénateur Benedito Valadares, p. 9. A similar defense of the continued need of public (inter-governmental) funds to finance projects of national development in emerging countries was presented by one of Vargas' main advisers, Rômulo de Almeida, in a speech made at the United Nations annual conference in 1953. Detailed information can be found in Fundo Benedito Valadares Bva.ig 1946.05.28, CPDOC Archive.

${ }^{23}$ For the case of industrial workers in São Paulo and Rio, see also Fifty Years in Five and What is in it for Us? Development Promotion, Populism, Industrial Workers and the Case of Carestia in 1950s Brazil. Journal of Latin American Studies, volume 44, issue 02, June 2012, p. 261-284.

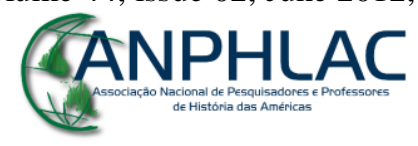

Revista Eletrônica da ANPHLAC, ISSN 1679-1061, №. 22, p. 296-326, Jan./Jun., 2017.

http://revista.anphlac.org.br 


\section{Development Promotion and Foreign Policy: The Case of Operation Pan-America}

The aftermath of World War II posed new challenges and opportunities for Latin America. The experiences of the Good Neighbor Policy which defined the 1930s and the war had fostered a sense that more cooperative patterns of interaction with the Colossus of the North could be sustained. This hopeful notion was dashed in the first months after the end of European hostilities. In effect, already at the Inter-American Conference of Chapultepec, in Mexico, in February and March of 1945 (thus before the formal end of the War), the United States indicated, to the great dismay of Latin American representatives, that its relations with the Western hemisphere would be largely defined by security concerns and new global geopolitical commitments which would place Latin America, once again, in the backseat of the country's foreign policy priorities. The new conservative guidelines for the United States' treatment of Latin America were all but confirmed in the Rio and Bogota Conferences of 1947 and 1948 , respectively; and throughout the 1950s as a whole the United States did not offer much respite in this regard to the region. (LOPEZ-MAYA, 1995, p. 135-149) In fact, as early as in 1953, soon after General Dwight Eisenhower had begun his first presidential term, the United States started to modify the course of foreign policy the country had followed during the previous 20 years of Democratic rule, particularly under FDR. In this sense, particularly relevant for the Western hemisphere, the new US president hoped to close ranks with the nations of the region so that the specter of Communism could be kept at bay. Significant changes in the US policies toward the nations of Latin America ensued. Foreign aid to the region was sharply reduced and loans from the United States Export-Import (Exim) Bank to regional governments were almost entirely curtailed. Namely, there was a reduction in disbursements from about US\$147 million in 1952 to only $\$ 7.6$ million dispensed in $1953 .^{24}$

In direct contrast to the stance held by the new American administration, most Latin American governments of the first half of the decade argued that their nation's

\footnotetext{
${ }^{24}$ Export-Import Bank, Semiannual Report. (Washington. D.C., 1953), p. 23.

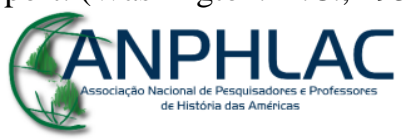

Revista Eletrônica da ANPHLAC, ISSN 1679-1061, №. 22, p. 296-326, Jan./Jun., 2017. http://revista.anphlac.org.br
} 
primary need was not securing their country's borders from the threat of foreign ideological infiltration, but rather addressing widespread poverty and underdevelopment at home. In Brazil, the abandonment of Truman's Point Four program of economic assistance directly affected the country's developmental plans, and the extinction of the Joint Brazil-United States Economic Commission (JBUSDC), in mid-1953, eliminated the most important financial source the country had at its disposal to finance projects of infrastructure reform. Hoping to curb the sense of frustration in Latin America, the Republican administration eventually agreed to hold discussions about the economic prospects of the region, and formal conversations began taking place at the InterAmerican Conference held in Rio de Janeiro in 1954. Despite having concurred to meet with regional leaders, US representatives nonetheless continued to assert, in multiple occasions, that their role in the region was primarily that of facilitating international economic cooperation among private agents. In fact, Eisenhower had run a presidential campaign largely based on the platform of curbing public expenditure and believed, along with some of his key cabinet members, that private sources of capital should be favored in financing developmental programs in poor countries of the continent. ${ }^{25}$

The United States president's strong personal views on the matter notwithstanding, a few members of the administration pursued divergent positions regarding how to support the development goals of countries in the region. In 1953, Assistant Secretary of State for Latin American Affairs, John M. Cabot, for one, questioned whether foreign investment could resolve all of Latin American's economic problems. In his view, "[...] even in countries with favorable tax and investment laws, foreign investors stayed away because of an inadequate economic infrastructure and poor human resources." 26 Attempting to act on the matter, the US diplomat suggested

\footnotetext{
${ }^{25}$ United Nations, International Cooperation in Latin American: A Development Policy. Prepared for the Meetings of Ministers of Economy for the Fourth Extraordinary Meeting of the Inter-American Economic and Social Council of the Organization of the American States, to be held in Rio de Janeiro in November 1954. (New York: 1954). See also Stephen G. Rabe, Eisenhower and Latin America: The Foreign Policy of Anticommunism. (Chapel Hill: University of North Carolina Press, 1988), p. 65.

${ }^{26}$ John M. Cabot, Letter to Secretary Dulles, 28 March 1953. Published by the Department of State, Agency for International Development, Overseas Loans and Grants, Volume 6. (Washington D.C., 1954), p. 221.
}

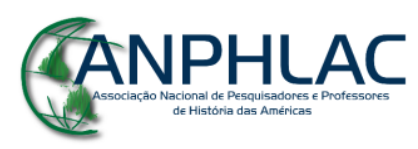

Revista Eletrônica da ANPHLAC, ISSN 1679-1061, №. 22, p. 296-326, Jan./Jun., 2017. 
that the Exim Bank assign US\$1 billion in public long-term loans to Latin America over the course of five years in order to support development projects in the area of infrastructure (i.e. transportation and communications networks). Cabot's position was largely based on the fact that Latin American nations had a favorable credit history with the Exim Bank, and he even came to believe that only by providing this type of overt material support, would the United States "[...] be able to convince our Latin American friends that our friendship is more than pious platitudes, that cooperation with us does benefit them and does raise their living standards, and that our democratic capitalism is far better for them than Communism with its rosy promises.",27

Given this challenging hemispheric scenario, the second Vargas Administration (1951-54) had as one of its main foreign policy goal improving Brazil's bargaining power vis-à-vis the United States so that he could obtain the funds he needed to implement his bold industrial goals. To be sure, Vargas had, naively, as it turned out, believed that this general objective could be pursued by strengthening the scope of mutual projects between the two countries, particularly in the area of infrastructural reform. It should not be hard, therefore, to imagine the damaging effects that the US government unilateral position to refuse any overt involvement in supporting economic development projects in Latin America exerted over the Brazilian administration at the time. In concrete terms, it would take the coming of a new political administration to make possible the implementation of more constructive bilateral diplomatic relations between these two traditionally aligned nations. In effect, in the throes of Vargas' suicide in August, 1954, Juscelino Kubitschek was elected president in October 1955 on the basis of a similarly ambitious national development platform which included a foreign policy also centered on the promotion of a more diversified and beneficial commercial relationship between Brazil and the international community, particularly with the Western hemisphere. The new Brazilian president thus actively sought more favorable terms of international loans targeted to developing nations and repeatedly stressed the urgent need that Brazil, along with all other Latin American countries had

\footnotetext{
${ }^{27}$ Ibid., p. 222.
}

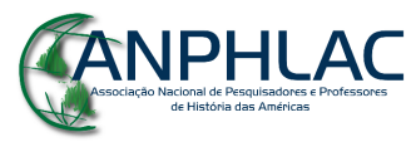

Revista Eletrônica da ANPHLAC, ISSN 1679-1061, №. 22, p. 296-326, Jan./Jun., 2017. 
to increase the pace of their economic growth. Moreover, Kubitschek believed that the United States had a 'moral obligation' and a 'historical debt' to provide the required resources to support the development ambitions of nations in the non-industrialized world. $^{28}$

Towards reshaping the hemispheric context towards more supportive conditions to implement his bold development goals, the new Brazilian president found a potential welcoming ground to pursue a new regional diplomatic overture in mid-year 1958. It was then that, after Henry Holland left the State Department, his immediate successor, Richard Rubottom, began directing the attention of the US administration to the deteriorating economic conditions in Latin America. These calls were so vocal that Rubottom eventually convinced Vice-president Richard Nixon to conduct a new diplomatic tour throughout the region. The trip was to coincide with the Argentine presidential inauguration of Arturo Frondizi in May, but the journey turned out to be a major political disaster as, after visiting Buenos Aires, Nixon was harassed by protesting students in Lima, and was nearly assaulted in Caracas by a mob that blamed the United States for Latin America's social ills. Examining these events in a letter sent directly to President Eisenhower on May 28, the same year, Kubitscheck conveyed his personal solidarity and sympathy against the aggression that the American vicepresident had suffered during his trip to the region. ${ }^{29}$ What is more, he suggested overhaul in the realm of Inter-American relations from ideologically driven positions to a new stance guided by the overarching goal of national development promotion, making sure to ground his efforts in the rising regional interest and concerns about national development. In fact, the Brazilian president sought and found enthusiastic support for his initiatives among key regional leaders, such a Frondizi and especially the Colombian president Lleras Camargo, with whom Kubitschek would later write a report

\footnotetext{
${ }^{28}$ See Robert J. Alexander, Juscelino Kubitscheck and the Development of Brazil (Athens, Ohio: State University of Ohio Center for International Studies, Monographs in International Studies, 1991); and Juscelino Kubitschek de Oliveira, Interview with O Jornal do Brasil, July 17, 1959, published in Artigos e Entrevistas Sobre a Operação Pan-Americana (Rio de Janeiro: Ministério das Relações Exteriores, Seção de Publicações, 1960).

${ }^{29}$ Juscelino Kubitschek, Operación Pan Americana: Compilacion de Documentos - I (Rio de Janeiro: Servicio de Documentación de la Presidencia de la Republica, 1958.
}

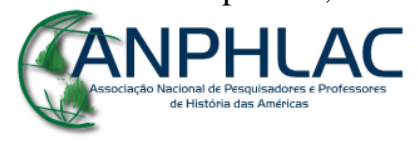

Revista Eletrônica da ANPHLAC, ISSN 1679-1061, №. 22, p. 296-326, Jan./Jun., 2017. 
on the Alliance for Progress at the request of the OAS. ${ }^{30}$

In assessing these important historical events, it is important to point out that although innovative in its format and conceptual underpinnings, in its moderate tone the Operation Pan-America fits in nicely within similar negotiating techniques utilized by previous administrations. Like Vargas, Kubitschek had been elected to carry out an ambitious agenda of development and he was very conscious of the problems his predecessor faced when attempting to pursue similar goals. He sought therefore, to formulate a more conciliatory, cooperative, and multilateral approach to obtain the needed foreign support to implement his plans. Brazil's president's strategy for addressing the regional problem of underdevelopment introduced the concept of regional cooperation in favor of development promotion within the realms of the conservative traditional agenda of Pan Americanism. ${ }^{31}$

Much in the same way, the very course of action the Brazilian president had selected proved to be strategic since by sending Eisenhower a personal letter, Kubitschek approached his political counterpart on a direct, less ideologically marred, and ultimately effective basis. In effect, in the document, the Brazilian leader not only proposed a revision of the traditional course of action that the United States conducted within the region but also expressed sympathy with the embarrassment a senior American official had suffered. This non-political approach convinced Eisenhower to send a personal envoy to Rio de Janeiro to hear from Kubitschek himself what his plans for the Operation entailed. ${ }^{32}$ What is more, the Brazilian president astutely chose not to specify in his initial pronouncements on the topic the institutional format the Operation

\footnotetext{
30 Juscelino Kubitschek, Aide-Memoire for the First Preparatory Meeting of Pan-American Operation. Fundo Negrão de Lima: NL ad m 1958.05.28, CPDOC Archive and Relatório sobre a Aliança para o Progresso, apresentado pelo senador Juscelino Kubitschek, ex-presidente do Brasil em 15 de junho de 1963, em reunião da Organização dos Estados Americanos. Fundo Hermes Lima, HL pi Oliveira, JK. 1963.04.00, p. 13, CPDOC Archive.

${ }^{31}$ Ministério das Relações Exteriores, Metodologia da Operação Pan-Americana. Departamento Político e Cultural. (Rio de Janeiro, Julho de 1958) \& Documento Secreto do Ministro sobre a Gênese da Operação Pan-Americana. Fundo Negrão de Lima: NL ad m 1958.05.28, CPDOC Archive. Getúlio Vargas Foundation.

${ }^{32}$ The US president had already been advised on the need to pay closer attention to Latin America's growing economic problems by his brother and advisor Milton Eisenhower, whose tour through Latin America was later published in the book The Wine is Bitter, (Doubledays, 1963).
}

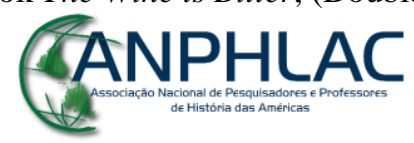

Revista Eletrônica da ANPHLAC, ISSN 1679-1061, №. 22, p. 296-326, Jan./Jun., 2017.

http://revista.anphlac.org.br 
should assume. In fact, Brazil's chief executive purposefully decided to be sufficiently vague, to both Eisenhower and other Latin-American leaders, about his proposed plan so that broad political support could be harnessed, especially from the economically liberal (market-driven) and politically conservative Republican administration. Finally, by following such conciliatory patterns, Kubitschek cleverly managed to promote a defense of national development which could be accepted in the United States by the hardline Republican administration in power.

Thus, even though the Brazilian diplomatic initiative failed to gather momentum in the Committee of the 21 American Republics - which had been set up in November 1958, under the auspices of the Organization of American States (OAS) to examine the Brazilian proposal - Kubitschek's new diplomatic project had become a central new focus of the State Department's analyses for the region. (TAFFET, 2007, p. 19) In effect, while economic support to Latin America in the 1950s had been essentially focused on military aid, pressured by State Department officials that had called attention to Latin American economic needs, in his final year in office Eisenhower came around in his positions regarding long-standing regional demands. In a special meeting of the OAS in Buenos Aires, in May of the same year the long-pursued idea of creating a regional financing institution geared towards aiding the development needs of Latin American nations finally received the needed support from the United States and eventually led to the creation of the Inter-American Development Bank (IADB). Moreover, in mid-1960, during a trip to South America which included stops in Brazil, Argentina, Chile, and Uruguay, Eisenhower was able to learn first-hand that even in the countries considered to be the most developed of the region, abysmal economic inequality persisted. After this trip, the US president approved the creation of the Social Progress Trust Fund, a government economic assistance program focused on social policies to governments willing to pursue reformist policies. (RABE, 1988, p. 141-144) Finally, the ultimate influence of Operation Pan-America can be seen, above all, in the very Charter of Punta del Este giving birth to the Alliance for Progress in 1961 and

\section{GANPHLAC}

Revista Eletrônica da ANPHLAC, ISSN 1679-1061, №. 22, p. 296-326, Jan./Jun., 2017. 
which acknowledged the OPA as its most important inspiration. ${ }^{33}$

\section{Concluding Remarks: Assessing Brazil's Middle-of-the-Road Path to Development}

Throughout the 1950s the agenda of fast-paced national development became prominent among the political leadership in Brazil. This important new historical trend was not limited by the constraints of political initiatives taking place within the domestic realm. Rather, this ambitious political push translated into ambitious political and economic initiatives carried out by Brazilian political and diplomatic authorities acting in an ever more interdependent international scenario. In this sense, it is no longer analytically sound to continue to examine the historical events taking place in Brazil during its so-called developmentalist decade as if exclusively circumscribed to the country's geographic boundaries. In fact, by alternatively placing the developmental dynamics of Brazil within the regional Latin American context, as well as tentatively within broad intellectual formulation taking place on a truly global scale, this piece advanced a new and potentially fruitful direction for future examinations. To be sure, key elements of the development policies being pursued by Brazilian authorities (e.g. state intervention and assertive foreign policy) did find resonance among leader of other developing nations and conceptual convergences existed between the propositions advanced by Brazilian and international intellectuals, particularly in regards to the search for overcoming the so-called colonial or semi-colonial condition.

\footnotetext{
${ }^{33}$ See Inter-American Relations Report: A Collection of Documents, Legislation, Descriptions of InterAmerican Organization, and Other Material Pertaining to Inter-American Affairs. Prepared by and presented to the Committee on Foreign Relations of the United States Senate. (Washington, D.C.: Government Printing Office, December 1988); and Lincoln Gordon, A New Deal for Latin America: The Alliance for Progress (Cambridge: Harvard University Press, 1963). It should be noted that in addition to the contemporary documents of the period indicating nominally the influence of the OPA in the formulation of the Alliance, this line of interpretation has also been corroborated by the recent historiography on the topic, which also indicate the support and enthusiasm from regional Latin American leaders for the plans and style of negotiation advanced by Kubitschek. Of special relevance see Christopher Darnton, Asymmetry and Agenda-Setting in US-Latin American Relations: Rethinking the Origins of the Alliance for Progress. Journal of Cold War Studies 14, no. 4 (2012): 55-92; and Tom Long, Latin America Confronts the United States: Asymmetry and Influence. (Cambridge University Press, 2015), especially chapter 2 .
}

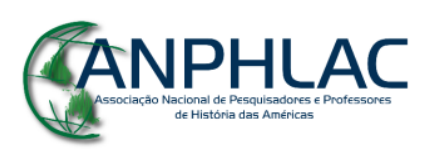

Revista Eletrônica da ANPHLAC, ISSN 1679-1061, №. 22, p. 296-326, Jan./Jun., 2017.

http://revista.anphlac.org.br 
When comparing the diplomatic projects carried out by Brazilian authorities in the period with those advocated by the political and intellectual leadership of countries that would eventually gather under the auspices of the Non-Aligned Movement, however, the conservative nature of the Brazil's approach to development also becomes evident. Yet, for what it designed, the Operation Pan-America - the most ambitious diplomatic project of the 1950s - proved successful in promoting Brazil's moderate developmental vision, initially in terms of enhancing Brazil's standing within the interAmerican context, and subsequently by providing alternatives overtures for the pursuit of more pragmatic developmental foreign policy projects. Tempting as it may be to see these events under the lenses of innovative accomplishments, one should nonetheless be cautious about the international and domestic restraints at work in the period. In fact, the mostly reformist industrial agenda of the Executive branch, as well as Kubitschek's personal political views, the country's largely conservative composition of the national Congress, and the anti-Communist logic quickly disseminating amidst the leadership of the armed forces and the urban middle sectors, all did pose profound hindrances towards a more overtly autonomous path in promoting its developmental agenda, similar to the one coalesced into the NAM in the 1960s. Similarly, the binary, pro-containment reasoning behind the US actions in the hemisphere proved to be a major hurdle to more ambitious and globally oriented moves on the part of Brazilian leaders. ${ }^{34}$

In this sense, the third way avant la lettre path of development pursued by Brazil had, to be sure, to trail a timid and thus only partially successful path aimed at balancing, at the same time, the rising expectations and needs of its burgeoning and ever more mobilized population with the growing domestic and global restrictions and impositions of the Cold War. More radical departures from this type of approach towards modernizing the country's economic bases would have likely resulted in

\footnotetext{
${ }^{34}$ Among the many works making this point, see Felipe Loureiro, The Alliance For or Against Progress? US-Brazilian Financial Relations in the Early 1960s. Journal of Latin American Studies 46, no. 2 (2014): 323-351; Sandra Halperin, Re-Envisioning Development: A horizontal perspective. (London: Routledge, 2013) and Michael Weis, The Twilight of Pan-Americanism: The Alliance for Progress, NeoColonialism, and Non-Alignment in Brazil, 1961-1964. The International History Review 23, no. 2 (2001): 322-344.
}

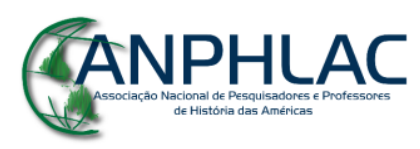

Revista Eletrônica da ANPHLAC, ISSN 1679-1061, №. 22, p. 296-326, Jan./Jun., 2017. 
breakdown of the democratic system and an even more top-down, technocratic and wealth concentrating course of development promotion, as the one implemented in the late 1960 s and early 1970 s by the authoritarian regime of the time. Yet, even though the Cuban events of 1959 onwards certainly exerted a more overt role in altering US policies towards Latin America, additional roots for the shift are to be found in the experiences surrounding new Brazilian diplomatic initiatives of the final years of the decade. In effect, the more-than-late-in-coming support from the United States for the creation of the IDB in 1960 and, soon after, the launching of the Alliance for Progress needs, once and for all, to be reinterpreted as having also resulted from the dissemination of development-oriented policies by Brazilian political, intellectual, and diplomatic leaders in that country's mid-century developmental experiences.

\section{Bibliography}

$\underline{\text { Primary Sources Consulted }}$

CABOT, John M. Letter to Secretary Dulles, 28 March 1953. Washington, D.C.: Department of State, Agency for International Development, Overseas Loans and Grants, Volume 6, 1954.

CAPANEMA, Gustavo. Discurso proferido pela delegação brasileira na segunda reunião preparatória para Conferência das Nações Unidas sobre Comércio e Desenvolvimento, em 21 de maio de 1956. Fundo Gustavo Capanema: GC L 1956.11.14, CPDOC Archive.

. Opening Statement of the Head of the Brazilian Delegation at the New Delhi Conference on Education for Development of UNESCO. November 1956. Fundo Gustavo Capanema: GC L 1956.05.23, p. 2, CPDOC Archive.

EXPORT-IMPORT BANK, Semiannual Report. Washington. D.C., 1953.

FINAL COMMUNIQUÉ OF BANDUNG. Documents on International Affairs, 1955.

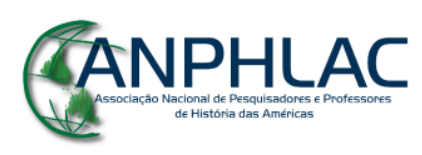

Revista Eletrônica da ANPHLAC, ISSN 1679-1061, №. 22, p. 296-326, Jan./Jun., 2017.

http://revista.anphlac.org.br 
Oxford: Oxford University Press, 1958.

IBGE. Estatísticas Históricas do Brasil: Séries Socio-Econômicas, Demográficas e Sociais, 1950-1988. Rio de Janeiro: Instituto Brasileiro de Geografia e Estatísticas, 1990.

OLIVEIRA, Juscelino Kubitschek de. Aide-Memoire for the First Preparatory Meeting of Pan-American Operation. Fundo Negrão de Lima: NL ad m 1958.05.28, CPDOC Archive.

ORGANIZAÇÃO DOS ESTADOS AMERICANOS. Relatório sobre a Aliança para o Progresso, apresentado pelo senador Juscelino Kubitschek, ex-presidente do Brasil em 15 de junho de 1963, em reunião da Organização dos Estados Americanos. Fundo Hermes Lima, HL pi Oliveira, JK. 1963.04.00, p. 13, CPDOC Archive.

MINISTÉRIO DAS RELAÇÕES EXTERIORES. Roteiro da declaração feita por Lucas Lopes ao Secretário de Estado John F. Dulles em reunião no Palácio do Itamaraty em agosto de 1958. Fundo Lucas Lopes LL pi Lopes, L. 1958.08.06, CPDOC Archive.

- Metodologia da Operação Pan-Americana. Rio de Janeiro: Departamento Político e Cultural, 1958.

PRESIDÊNCIA DA REPÚBLICA. Relatório geral de exportações e importações, 19471960. Rio de Janeiro, 1960.

UNITED NATIONS. International Cooperation in Latin American: A Development Policy. Prepared for the Meetings of Ministers of Economy for the Fourth Extraordinary Meeting of the Inter-American Economic and Social Council of the Organization of the American States, to be held in Rio de Janeiro in November 1954. New York, 1954.

UNITED STATES SENATE. Inter-American Relations Report: A Collection of Documents, Legislation, Descriptions of Inter-American Organization, and Other Material Pertaining to Inter-American Affairs. Washington, D.C.: Government Printing Office, December 1988.

VALADARES, Benedito. Discours prononcé par le Sénateur Benedito Valadares, représentant du Brésil au Comité Economique et Social de la 11ieme Session de Assemblé Générale de l'ONU, sur le Problème de l'Assistance Technique aux Pais

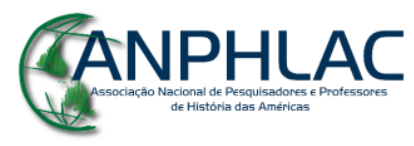

Revista Eletrônica da ANPHLAC, ISSN 1679-1061, №. 22, p. 296-326, Jan./Jun., 2017.

http://revista.anphlac.org.br 
Sous-Développés. Speech made in New York, in November, 1956. Fundo Benedito Valadares BVa cs 1956.10 .17 , p. 8, photogram 856, CPDOC Archive.

\section{$\underline{\text { Works Cited }}$}

ABREU, Alzira Alves de. Os suplementos literários: os intelectuais e a imprensa nos anos 50. In: ABREU, Alzira Alves de. (Ed.). A Imprensa em Transição: O Jornalismo Brasileiro nos Anos 50. Rio de Janeiro: Editora da FGV, 1996, pp. 13-60.

ALEXANDER, Robert J. Juscelino Kubitscheck and the Development of Brazil. Athens, Ohio: State University of Ohio Center for International Studies, Monographs in International Studies, 1991.

AMSDEN, Alice. Asia's Next Giant: South Korea and Late Industrialization. Oxford: Oxford University Press, 1989.

AHN, Yeonmi. The Political Economy of Foreign Aid: The Nature of American Aid and Its Impact on the State-Business Relationship in South Korea, 1945-1972. Ph.D. Dissertation, Yale University, 1992.

ARNDT, H. W. Economic Development: The History of an Idea. Chicago: University of Chicago Press, 1987.

BENEVIDES, Maria Victoria de Mesquita. O governo Kubitschek: desenvolvimento econômico e establidade política, 1956-1961. Rio de Janeiro: Paz e Terra, 1976.

BERGERON, Suzanne. Fragments of Development: Nation, Gender, and the Space of Modernity. Ann Arbor: University of Michigan Press, 2004.

BOETKE, Peter J. (Ed.). The Collapse of Development Planning. New York: New York University Press, 1994.

BRADELY, Mark P. Decolonization, the global South, and the Cold War, 1919-1962. In: LEFFLER, Melvyn P.; WESTAD, Odd Arne (Eds.). The Cambridge History of the Cold War. Volume 1. Cambridge: Cambridge University Press, 2010.

BUENO, Clodoaldo; CERVO, Amado. A Política Externa Brasileira, 1822-1985. São

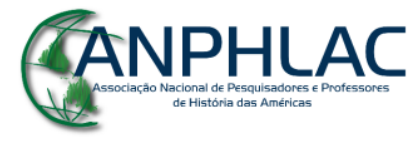

Revista Eletrônica da ANPHLAC, ISSN 1679-1061, №. 22, p. 296-326, Jan./Jun., 2017. http://revista.anphlac.org.br 
Paulo: Ática, 1986.

CALDAS, Ricardo W. A Politica Externa do Governo Kubitscheck. Brasilia: Thesaurus, 1996.

CARDOSO, Fernando Henrique. Autoritarismo e Democratização. Rio de Janeiro: Paz e Terra, 1975.

CHATTERJEE, Partha. Nationalist Thought and the Colonial World: A Derivative Discourse. Minneapolis: University of Minnesota, 1993.

CHIBBER, Vivek. Locked in Place: State-Building and Late Industrialization in India. Princeton: Princeton University Press, 2003.

CORBISIER, Roland. Formação e Problema da Cultura Brasileira. Rio de Janeiro: ISEB, 1959.

. JK e a luta pela Presidência. Rio de Janeiro: Duas Cidades, 1976.

DARNTON, Christopher. Asymmetry and Agenda-Setting in US-Latin American

Relations: Rethinking the Origins of the Alliance for Progress. Journal of Cold War Studies, 14, no. 4, 2012, p. 55-92.

EVANS, Peter B. Embedded Autonomy: States \& Industrial Transformation. Princeton: Princeton University Press, 1995.

Predatory, Developmental, and Other Apparatuses: A Comparative Political Economy Perspective on the Third World State. Sociological Forum, Vol. 4, No. 4, Special Issue: Comparative National Development Theory and Facts for the 1990s. (Dec., 1989), p. 561-587.

FASSY, Amaury Santos. JK: o maior estadista do século XX. Brasília: Thesaurus, 2000.

FISHLOW, Albert. Some Reflections on Comparative Latin American Performance and Policy. Helsinki: World Institute for Development Economics Research, 1987.

FURTADO, Celso. Desenvolvimento e Subdesenvolvimento. Rio de Janeiro: Fundo de Cultura, 1961.

. Formação Econômica do Brasil. São Paulo: Fundo de Cultura, 1959.

GERSCHENKRON, Alexander. Economic Backwardness in Historical Perspective.

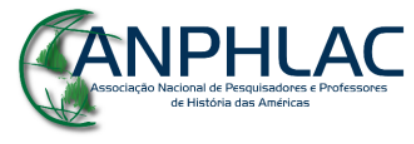

Revista Eletrônica da ANPHLAC, ISSN 1679-1061, №. 22, p. 296-326, Jan./Jun., 2017.

http://revista.anphlac.org.br 
Cambridge: Harvard University Press. 1962.

GOMES, Angela de Castro. O Brasil de JK. Rio de Janeiro: FGV, 1991.

GORDON, Lincoln. A New Deal for Latin America: The Alliance for Progress.

Cambridge: Harvard University Press, 1963.

HAGGARD, Stephan. Pathways from the Periphery: The Politics of Growth in the Newly Industrializing Countries. Ithaca, NY: Cornell University Press, 1990.

HAGOPIAN, Frances. The Politics of Oligarchy: The Persistence of Traditional Elites in Contemporary Brazil. Ph.D. Dissertation, Department of Political Science, MIT, 1986.

HALPERIN, Sandra. Re-Envisioning Development: A horizontal perspective. London: Routledge, 2013.

HIRSCHMAN, Albert O. Journeys Toward Progress: Studies of Economic PolicyMaking in Latin America. New York: W.W. Norton, 1963.

. The Strategy of Economic Development. New Have: Yale University Press, 1958.

. Ideologies of Economic Development in Latin America. In: HIRSCHMAN, Albert (Ed.) Latin American Issues, Essays, and Commnents. New York: The Twentieth Century Fund, 1961.

IORIS, Rafael R. Transforming Brazil: A History of National Development in the Postwar Era. New York: Routledge, 2014.

Fifty Years in Five and What is in it for Us? Development Promotion, Populism, Industrial Workers and the Case of Carestia in 1950s Brazil. Journal of Latin American Studies, volume 44, issue 02, June 2012, p. 261-284.

JOHNSON, Chalmers. MITI and the Japanese Miracle: The Growth of Industrial Policy, 1925-1975. Stanford: Stanford University Press, 1982.

JAGUARIBE, Hélio. Condições Institucionais do Desenvolvimento. Rio de Janeiro: ISEB, 1958.

. O Nacionalismo na Atualidade Brasileira. Rio de Janeiro: ISEB, 1958.

\section{GANPHLAC}

Revista Eletrônica da ANPHLAC, ISSN 1679-1061, №. 22, p. 296-326, Jan./Jun., 2017.

http://revista.anphlac.org.br 
KOHLI, Atul. State-Directed Development: Political Power and Industrialization in the Global Periphery. Cambridge: Cambridge University Press, 2004.

LONG, Tom. Latin America Confronts the United States: Asymmetry and Influence. Cambridge University Press, 2015.

LOPEZ-MAYA, Margarita, The Change in the Discourse of US-Latin American Relations from the End of the Second World War to the Beginning of the Cold War. Review of International Political Economy, vol. 2, No. 1 (Winter, 1995), p. 135-149.

LOUREIRO, Felipe. The Alliance For or Against Progress? US-Brazilian Financial Relations in the Early 1960s. Journal of Latin American Studies 46, no. 2, 2014, p. 323351.

LOUZEIRO, José. JK: o otimismo em pessoa. Rio de Janeiro: Ediouro, 1996.

LOVE, Joseph L. A Construção do Terceiro Mundo: Teorias do Subdesenvolvimento na Romênia e no Brasil. São Paulo: Paz e Terra, 1998. Raul Prebisch and the Origins of the Doctrine of Unequal Exchange. Latin American Research Review 15, no. 3, 1980, p. 45-72.

MENDES DE ALMEIDA, Candido. Nacionalismo e Desenvolvimento. Rio de Janeiro: Instituto Brasileiro de Estudos Afro-Asiáticos, 1963.

NKRUMAH, K. African Prospects. Foreign Affairs. August 1958.

OLIVEIRA, Juscelino Kubistchek de. Exposição da Operação Pan-Americana às Forças Armadas no Palácio do Itamaraty, no dia 17 de julho de 1958. Rio de Janeiro: Ministério das Relações Exteriores, Seção de Publicações, 1958. Interview with O Jornal do Brasil. July 17, 1959, published in Artigos $e$ Entrevistas Sobre a Operação Pan-Americana. Rio de Janeiro: Ministério das Relações Exteriores, Seção de Publicações, 1960.

Mensagem ao Congresso Nacional. Rio de Janeiro: Departamento de Imprensa Nacional, 1956.

Operación Pan Americana: Compilacion de Documentos - I. Rio de Janeiro: Servicio de Documentación de la Presidencia de la Republica, 1958.

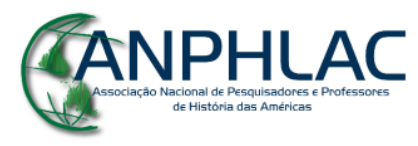

Revista Eletrônica da ANPHLAC, ISSN 1679-1061, №. 22, p. 296-326, Jan./Jun., 2017. http://revista.anphlac.org.br 
PEMPEL, T. K. The Developmental Regime in a Changing World Economy. In: WOO-CUMINGS, Meredith (Ed.). The Developmental State. Ithaca: Cornell University Press, 1999.

PINEDA, Yovanna. Industrial Development in a Frontier Economy. The Industrialization of Argentina, 1890-1930. Stanford University Press, 2009.

PINHEIRO, Letícia. Ação e omissão: a ambiguidade da política brasileira frente ao processo de descolonização africana, 1946-1960. Dissertação de Mestrado defendida no Instituto de Relações Internacionais da PUC-RJ, 1988.

PRADO, Maria Emilia. Os intelectuais e a eterna busca pela modernização do Brasil: o significado do projeto nacional-desenvolvimentista das décadas de 1950-60. História Atual Online, no. 15, 2008, p. 19-27.

PREBISCH, Raul. The Economic Development of Latin America and its Principal Problems. New York: United Nations Department of Economic Affairs, 1950.

QUEUILLE, Pierre. Histoire de l'afro-asiatisme jusqu'à Bandung. Paris: Payot, 1965.

RABE, Stephen G. Eisenhower and Latin America: The Foreign Policy of Anticommunism. Chapel Hill: University of North Carolina Press, 1988.

RAMOS, Alberto Guerreiro. A Redução Sociológica. Rio de Janeiro: ISEB, 1958.

RODRIGUEZ, Marly. A década de 50: Populismo e metas desenvolvimentistas no Brasil. São Paulo: Ática, 1994.

RODRIGUEZ, Octavio. Teoria do Subdesenvolvimento da Cepal. Rio de Janeiro: Forense Universitária, 1981.

ROXBOROUGH, Ian. Theories of Underdevelopment. London: Macmillan, 1979.

SACHS, Ignacy. Capitalismo de estado e subdesenvolvimento. Petrópolis: Vozes, 1969.

SANTOS, Joaquim Ferreira dos. Feliz 1958: O ano que não deveria terminar. São Paulo: Record, 1997.

SANTOS, Pedro Augusto Gomes. A classe média vai ao paraíso: JK em Manchete. Porto Alegre: Edipucrs, 2002.

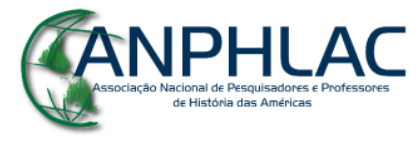

Revista Eletrônica da ANPHLAC, ISSN 1679-1061, №. 22, p. 296-326, Jan./Jun., 2017. http://revista.anphlac.org.br 
SCHNEIDER, Ben Ross. The Desarollista State in Brazil and Mexico. In: WOOCUMINGS, Meredith (Ed.). The Developmental State. Ithaca: Cornell University Press, 1999.

SCOTT, James. Seeing Like a State: How Certain Schemes to Improve the Human Condition Have Failed. New Haven: Yale University Press, 1998.

SHAPIRO, Helen. State Intervention and industrialization: The Origins of the Brazilian Automotive Industry. Ph.D. Dissertation, Department of Economics, Yale University, 1988.

SHEAHAN, John. Early Industrialization and Violent Reaction: Argentina and Brazil. University of Sussex: Institute of Development Studies, 1982. Discussion Paper 176.

SIKKINK, Katryn. Ideas and Institutions: Developmentalism in Brazil and Argentina. Ithaca: Cornell University Press, 1991.

SILVA, Alexandra Mello e. A Política Externa de JK: a Operação Pan-Americana. Dissertação de Mestrado defendida no Instituto de Relações Internacionais da PUC-RJ, 1992.

SILVA, Hélio Silva; CARNEIRO, Maria. Juscelino, o desenvolvimento, 1956-61. São Paulo: Editora Três, 1983.

SZUSTERMAN, Celia. Frondizi and the Politics of Developmentalism in Argentina, 1955-62. Pittsburgh: University of Pittsburgh Press, 1993.

TAFFET, Jeffrey F. Foreign Aid as Foreign Policy: The Alliance for Progress in Latin America. New York: Routledge, 2007.

TOLEDO, Caio Navarro de. ISEB: Fábrica de ideologias. São Paulo: Ática, 1977. (Org.). Intelectuais e política no Brasil: a experiência do ISEB. São Paulo: Revan, 2005.

VELIZ, Claudio. The Centralist Tradition in Latin America. Boulder: Westview Press, 1980.

VIEIRA PINTO, Álvaro. Ideologia e Desenvolvimento Nacional. Rio de Janeiro: ISEB, 1960.

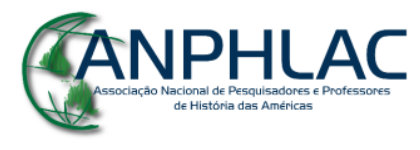

Revista Eletrônica da ANPHLAC, ISSN 1679-1061, №. 22, p. 296-326, Jan./Jun., 2017. http://revista.anphlac.org.br 
VIZENTINI, Paulo G. F. As Relações Exteriores do Brasil:1945-1964. Petrópolis: Vozes, 2004.

WADE, Robert. Governing the Market: Economic Theory and Role of Government in East Asian Industrialization. Princeton: Princeton University Press, 1990.

WALKER, Michael. The Cold War and the Making of the Modern World. London: Fourth State Press, 1993.

WALLERSTEIN, Immanuel. The Concept of National Development, 1917-1989: Elegy and Requiem. American Behavioral Scientist, 35, p. 517-529.

WEIS, Michael. The Twilight of Pan-Americanism: The Alliance for Progress, NeoColonialism, and Non-Alignment in Brazil, 1961-1964. The International History Review 23, no. 2, 2001, p. 322-344.

\section{GANPHLAC}

Revista Eletrônica da ANPHLAC, ISSN 1679-1061, №. 22, p. 296-326, Jan./Jun., 2017. http://revista.anphlac.org.br 